\title{
Weathering of andesite monuments in archaeological sites
}

\author{
Çağlayan D. Kaplan ${ }^{1}$, Fulya Murtezaoğlu*, Başak İpekoğlu ${ }^{2}$, Hasan Böke $^{3}$ \\ Department of Architectural Restoration, Izmir Institute of Technology, 35430 İzmir, Turkey
}

\section{A R T I C L E I N F O}

\section{Article history:}

Received 31 October 2012

Accepted 6 November 2012

Available online 19 February 2013

\section{Keywords:}

Stone weathering

Andesite

Archaeological site

Clay minerals

Conservation

\begin{abstract}
A B S T R A C T
Archaeological sites, which are the integral parts of cultural heritage, have to be conserved as a whole to have a variety of information about past societies. In this study, the weathering problems of unburied and newly excavated andesite monuments in Aigai archaeological site (Manisa, Turkey) were investigated for the purpose of their conservation. With this intent, the basic physical properties, mineralogical and chemical compositions and microstructural properties of sound and weathered samples were determined by using XRD, SEM-EDS, FT-IR and TGA analysis. Results of the study indicated that the weathering mechanisms of unburied and post-excavated andesite differ from each other. The main weathering problems observed on the unburied stones are mainly increasing microcracks from inner parts to the surfaces, deposition of iron oxides and microbiological colonization due to climatic conditions of the site. In the newly excavated areas, calcium carbonate deposition, accumulation of clay minerals and microbiological colonization are the main weathering problems due to weathering of silica minerals through the action of carbon dioxide and water during burial.
\end{abstract}

(C) 2013 Elsevier Masson SAS. All rights reserved.

\section{Introduction}

The archaeological sites, which reveal earlier activities of ancient civilizations, are nonrenewable cultural sources and should be conserved as a whole. The need for preservation of archaeological sites was declared for the first time in Madrid Conference held in 1904 [1]. The conference entitled the archaeological sites as "dead monuments" and adopted the conservation of these monuments to prevent their falling into ruin. After the Madrid Conference, several policies concerning the preservation of archaeological sites were enacted. Among them, Athens Charter (1931) first declared the preservation of the archaeological monuments and findings as an interdisciplinary work. After the declaration of the Athens Charter, the importance of interdisciplinary collaboration by workers, who have advanced archaeological knowledge and the importance of using advanced technologies, were emphasized by many other charters and policies [2].

With the declaration of the Athens Charter, the concept of the conservation problem gained a new dimension. It recommended reburying the excavated sites if the proper maintenance preventions could not be maintained. The Recommendation on International Principles Applicable to Archaeological Excavations

\footnotetext{
* Corresponding author. Tel.: +90 232 7507029; fax: +90 2327507012.

E-mail addresses: caglayankaplan@iyte.edu.tr (Ç.D. Kaplan), fulyamurtezaoglu@iyte.edu.tr (F. Murtezaoğlu),basakipekoglu@iyte.edu.tr (B. İpekoğlu), hasanboke@iyte.edu.tr (H. Böke).

1 Tel.: +90 232 7507029; fax: +90 2327507012

2 Tel.: +90 232 7507075; fax: +90 2327507012

3 Tel.: +90 232 7507035; fax: +90 2327507012 .
}

accepted in 1956, strongly recommended leaving archaeological sites partially or totally unexcavated in case of not maintaining the sufficient excavation methods, proper maintenance and conservation methods [3]. The threats of unscientific excavations were emphasized again in the European Convention on the Protection of the Archaeological Heritage held in 1990 and renewed in 1992 [4]. All of these decisions have recommended the proper provision of sufficient archaeological management and the collaboration of professionals before excavating the sites for the purpose of conservation of ancient building materials. In accordance with the principles proclaimed in the international charters, investigation of the stone weathering mechanism is one of the main tasks of the conservation of archaeological monuments and sites. A number of studies have been carried out concerning physical [5-9], chemical [6-9] and biological [7-10] weathering process of stone material. The study reviewed by Dohne and Price (2010) [11] is the most comprehensive and excellent review concerning stone conservation including the weathering processes.

Weathering mechanisms of stone monuments in archaeological sites differ according to their conditions as post-excavated and unburied. The main factors effective in the weathering process of unburied stones are the mineralogical composition of the stone, climate, air pollution, differential stresses, biological formations, soluble salts, presence of clay minerals and human intervention $[11,12]$. The main factors that affect the weathering of buried stones are soil temperatures in different layers, soluble salts in soil structure, dissolved carbon dioxide, organic material content, soil reaction $(\mathrm{pH})$, vegetation cover and the particle size of the soil [13-16]. 

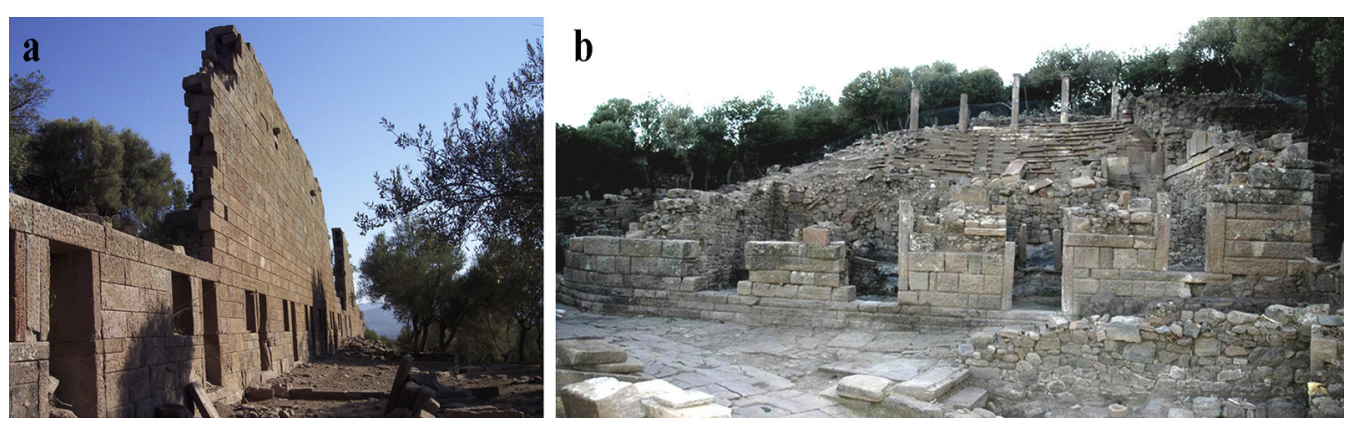

Fig. 1. General views of (a) Agora and (b) Bouleuterion.

After excavation of stones in an archaeological site, the rapid and massive humidity and temperature changes in the environment accelerate the weathering process of stones [15].

Andesite was a precious stone for ancient populations to construct their buildings because it is easily pliable material and the next most abundant volcanic rock after basalt [17-19]. In this study, the weathering of unburied and newly excavated andesites in archaeological sites is evaluated for the purpose of their conservation. The study was carried out on unburied and excavated andesite monuments in Aigai archaeological site in Turkey. The unburied andesite monument is the Agora which has been exposed to atmospheric conditions for almost 2300 years. The excavated example is the Bouleuterion (Senate Hall Building) which was buried hundreds of years and newly excavated. Through the course of time, it was a massive monument and laid for hundreds of years until the excavation works were started. The excavation works of the Bouleuterion began in 2004 and were completed in 2008 [20].

\section{Materials and methodologies}

\subsection{Studied buildings}

Aigai, which is also known Nemrutkale, is an ancient inland site in the northwest part of Turkey. It was one of the twelve settlements constructed by the Aeolians, who emigrated from Greece in the 1100s BC [21]. According to the information gathered from the excavations, some parts of Aigai were used as a Byzantine settlement in 12th and 13th centuries AD.

The studied Agora is a three-storied masonry building dating to late Hellenistic period (Fig. 1a). It is an L-shape planned building with the dimensions of $82.37 \mathrm{~m} \times 27.00 \mathrm{~m}$ in two wings and forms the upper agora with a stoa on the third floor level. It is located on a sloped site on the southeast of the city in the north-south direction. Two of its stories are below the artificial terrace level supporting the stoa on the third floor at its northwest. In the construction of the walls, cut-stones used in the outer and inner facings are put together integrating to the rubble core. On the outer facing, the cut-stones are located two abreast and one perpendicular to the facings [22].

The Bouleuterion (Fig. 1b), which is located on the northeast of Agora building, is considered to have been built in the late Hellenistic period, also. It is $23 \mathrm{~m} \times 15 \mathrm{~m}$ in dimensions from outer walls and $21.5 \mathrm{~m} \times 13 \mathrm{~m}$ from the interior walls. The borders of the Aigai Bouleuterion are linear from the outer section but the "cavea" (central part of the building where the audience used to sit) is curvilinear. The cavea is separated into two sections with stairs in the middle. From the number of sitting blocks, it may be determined that 150 people could occupy this section. Total level difference between the sitting platforms in the cavea is $3.5 \mathrm{~m} \mathrm{[23].} \mathrm{Walls,}$ columns and the sitting platforms were constructed of andesite. Stone platforms were put together with soil infill on the natural slope of the site. The façades of the building was designed in Doric order. The west façade are made of rubble stone and the north, east and south façades of the building are cut stone. The shape and the bonding system of the stones are more regular in the eastern and southern façades of the building [23].

\subsection{Climate}

The environmental parameters such as temperature, humidity, rainfall and wind speed are the major factors that affect the weathering process of the building materials [12]. In this study, the average values of climatic data of the site for ten years (1996-2006) were evaluated considering data taken from The General Directorate of State Meteorological Affairs, Ankara.

During the winter months (December, January and February), ambient temperature and dew point temperature are low and close to each other and relative humidity is high. In these months, the rainfall is higher than $100 \mathrm{~mm} / \mathrm{m}^{2}$ and the wind speed changes between $1.4-1.8 \mathrm{~m} / \mathrm{s}$. Frosty days were generally observed in these months. During the summer months (June, July and August), temperatures increase and relative humidity decreases (Fig. 2a). The
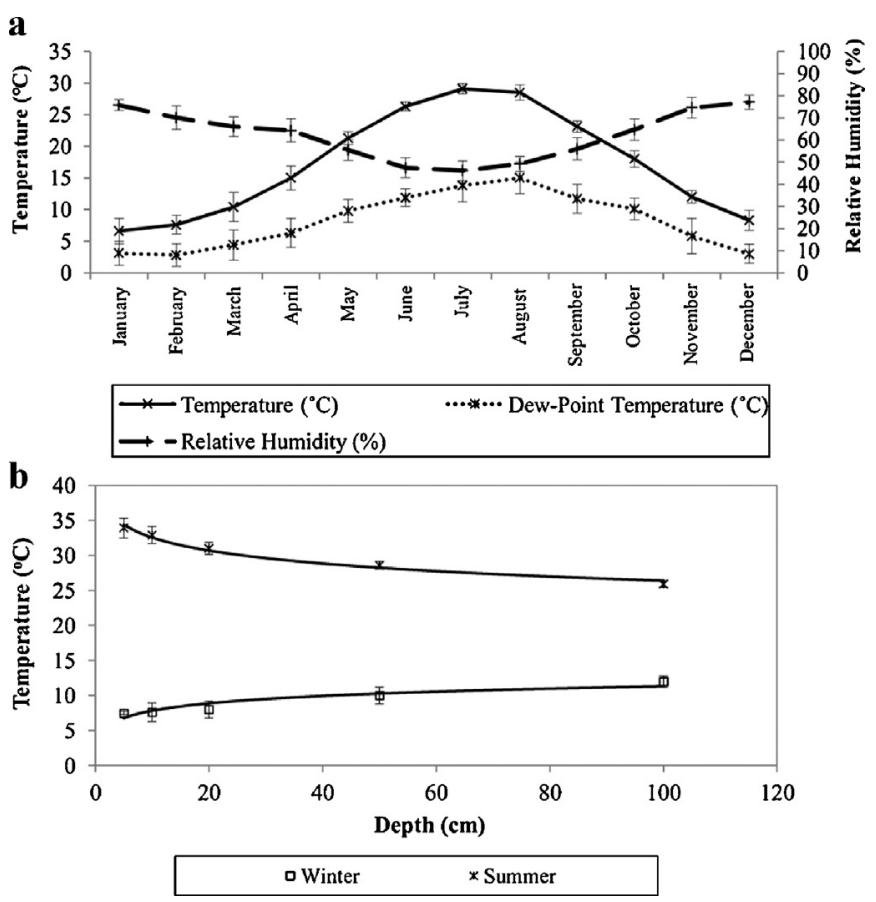

Fig. 2. Average values of (a) the average monthly values of ambient temperature, relative humidity and dew-point temperature, (b) the average seasonal values of soil temperatures between the years 1996 and 2006.

Source: General Directorate of State Meteorological Affairs Ankara. 

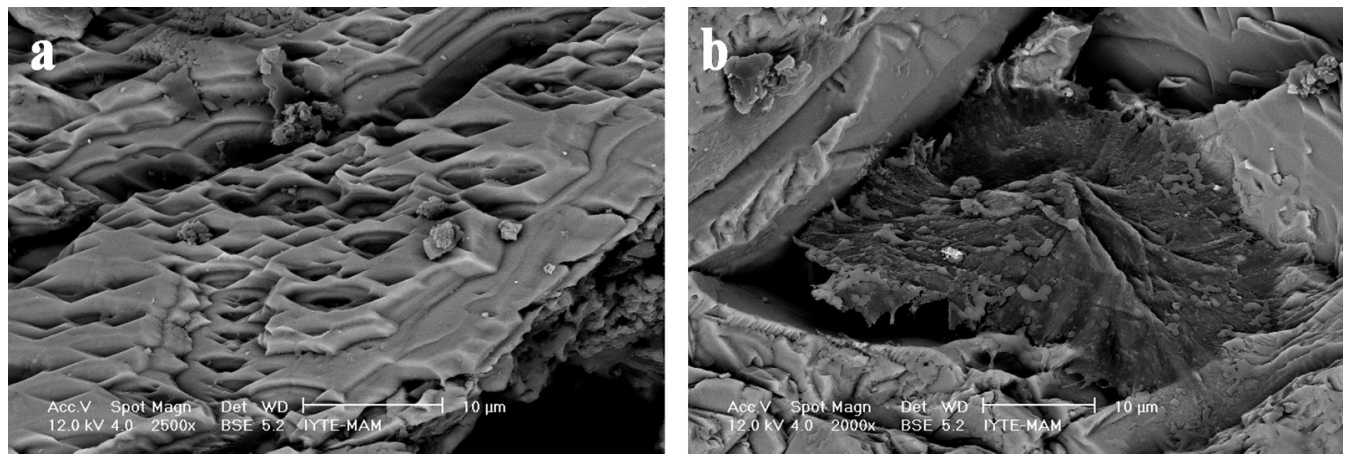

Fig. 3. BSE images of (a) void spaces and (b) glassy phase of microstructure of andesite.

rainfall is minimum ( $\left.>20 \mathrm{~mm} / \mathrm{m}^{2}\right)$ and the wind speed changes between $1.8-2.0 \mathrm{~m} / \mathrm{s}$ during these months.

The average values of soil temperatures could be taken up to $100 \mathrm{~cm}$ depth. The data of subsoil temperatures show that they increase in summer and decrease in winter through the surface of the ground (Fig. 2b). However, changes in temperature decrease below $20 \mathrm{~cm}$ depth and the seasonal temperatures get close to each other through the deeper parts of the soil. It can be estimated that the physical weathering of stone material caused by the temperature changes decrease in the subsoil environment.

\subsection{Tests}

The laboratory analyses were carried out on the four stone samples taken from the Agora and five stone and five soil samples from the excavated sections of the Bouleuterion without detriment to the buildings [22,23].

Porosity (\%) and bulk density $(\mathrm{g} / \mathrm{cm} 3)$ of all the stone samples were determined by the RILEM standard test methods [24]. Stone samples were first dried in an oven at $40^{\circ} \mathrm{C}$ for $24 \mathrm{~h}$, and their dry weights were determined by a precision balance (AND HF-3000G). Then, the samples were saturated with distilled water in a vacuum oven (Lab-Line 3608-6CE Vacuum Oven) and then were weighed by a precision balance using hydrostatic weighing method in distilled water.

Mineralogical compositions of three sound and six weathered stone samples and white depositions observed on newly excavated stones were determined by X-ray diffraction (XRD) analysis performed using a Philips X-Pert Pro X-ray diffractometer. Mineralogical compositions of clay minerals present on and inside the stones were determined by XRD and FT-IR spectroscopy. Five soil samples were sieved through less than $53 \mu \mathrm{m}$ and mineralogical compositions of these parts were analyzed in order to find out the sources of white deposition observed on excavated stone surfaces. In the FT-IR analysis, all the samples were mixed with $\mathrm{KBr}$ and pressed into pellets under approximately 10 tons $/ \mathrm{cm}^{2}$ pressures. The spectral measurements were carried out on a PerkinElmer-FTIR system spectrum BX spectrometer.

Chemical compositions of all stone samples, clay fractions and white depositions were determined by Philips XL 30S-FEG scanning electron microscope (SEM) equipped with X-ray energy dispersive system (EDS). Analyses were carried out on pellets prepared by pressing powder samples under 10 tons/cm2 pressures. Philips XL 30S FEG SEM coupled with X-ray EDS was used. Analyses were carried out on three different $2.5 \mathrm{~mm}^{2}$ areas of the pellets.

Petrographic and microstructural analyses were carried out by Scanning Electron Microscope and polarized microscope using Nikon ECLIPSE E400 POL Polarized Microscope.

The salt content in the stone were determined using an electrical conductivity meter (WTW MultiLine P3 pH/LF) [25]. The principle anions of salts such as sulfate $\left(\mathrm{SO}_{4}^{-}\right)$, chloride $\left(\mathrm{Cl}^{-}\right)$, nitrate $\left(\mathrm{NO}_{3}{ }^{-}\right)$, carbonate $\left(\mathrm{CO}_{3}{ }^{-2}\right)$ and phosphate $\left(\mathrm{PO}_{4}{ }^{-3}\right)$ were determined qualitatively by spot tests $[25,26]$.

\section{Results and discussion}

\subsection{Characteristics of unweathered andesite}

The density and porosity values of three sound andesite samples were between $2.3-2.4 \mathrm{~g} / \mathrm{cm}^{3}$ and $7.7-8.2 \%$ by volume, respectively. The pores were formed with the rising of gas from the interior of the stone structure during the cooling process of lava (Fig. 3a).

Petrographic and microstructural analysis indicated that andesite is mainly formed by rectangular shapes of feldspars (nearly $300 \mu \mathrm{m} \times 500 \mu \mathrm{m})$, biotite $(250 \mu \mathrm{m}$ in length), iron oxides $(100 \mu \mathrm{m} \times 100 \mu \mathrm{m})$, quartz minerals (smaller than $100 \mu \mathrm{m})$ and glassy phases (Fig. 3b). These results show that the andesites used in the site are fine grained (aphanitic) igneous rocks [27].

Stones samples are dominated by the minerals of microline, orthoclase and sanidine as potassium feldspars, albite as sodium feldspar, andesine, labradorite and anorthite as plagioclase feldspars, muscovite as mica, cristobalite, tridymite and quartz as quartz minerals, kyanite and mullite as aluminum silica and orthoferrosilite as magnesium silica minerals (Fig. 4a).

Andesite was composed primarily of silicon dioxide $\left(\mathrm{SiO}_{2}\right)$, aluminum oxide $\left(\mathrm{Al}_{2} \mathrm{O}_{3}\right)$ and iron oxide $\left(\mathrm{Fe}_{2} \mathrm{O}_{3}\right)$. The minor elements were sodium oxide $\left(\mathrm{Na}_{2} \mathrm{O}\right)$, potassium oxide $\left(\mathrm{K}_{2} \mathrm{O}\right)$, magnesium oxide ( $\mathrm{MgO}$ ) and calcium oxide ( $\mathrm{CaO})$ (Fig. 5). Considering these analyses, andesites can be classified as intermediate igneous rocks [18].

\subsection{Weathering of unburied andesite}

Climatic condition of the site is the main factor of the physical and chemical weathering of andesite. Process of weathering is mainly related to the temperature and relative humidity changes between day and night [5]. In the Aigai archaeological site, condensation and frost occurs mostly in winter months with increasing relative humidity and decreasing temperature. These conditions promote the physical weathering of the stone [5].

Physical weathering of stone can be defined by the determination of changes in density and porosity values of stones. Density and porosity values of three sound andesites were about $2.4 \mathrm{~g} / \mathrm{cm}^{3}$ and $8 \%$ by volume, respectively. However, the density values decrease to $2.0 \mathrm{~g} / \mathrm{cm}^{3}$ and porosity varies between $14.6 \%$ and $21.5 \%$ in weathered exterior parts of the stone.

Another sign of the weathering is the formation of microcracks at the stone surface. In this study, the microcracks $(5-50 \mu \mathrm{m})$ and small pores $(25-100 \mu \mathrm{m})$ from the surface to the inner part were determined by phase analysis of SEM images. It was observed that 

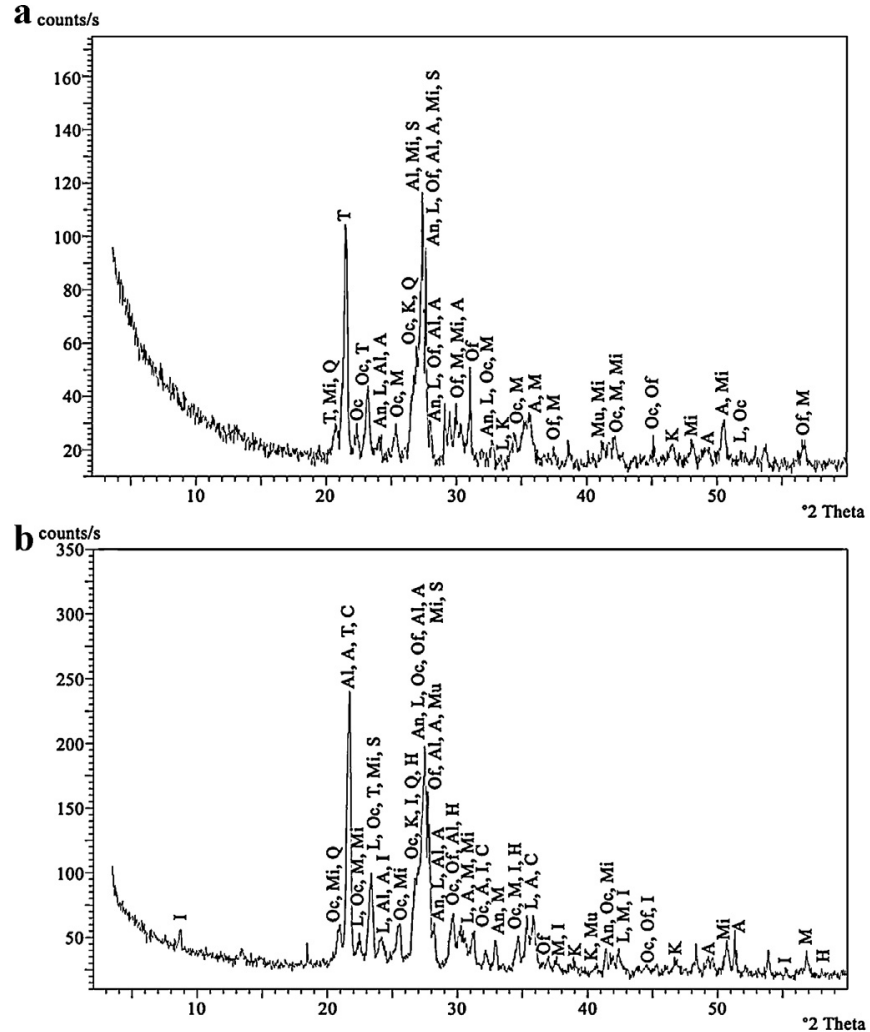

Fig. 4. XRD patterns of (a) unweathered andesite and (b) weathered exterior surface of andesite (A: Andesine (79-1148), Al: Albite high (83-1608), An: Anorthite (70-0287), K: Kyanite (72-1441), L: Labradorite (83-1368), M: Muscovite (76-0668), Mi: Microline (76-1238), Mu: Mullite (02-1160), Oc: Orthoclase (75-1190), Of: Orthoferrosilite (83-0668), Q: Quartz (83-2468), S: Sanidine (19-1227), T: Tridymite (42-1401)).

microcracks and small pores are higher in $3 \mathrm{~cm}$ depth from the surface to the inner parts in three weathered andesite samples (Fig. 6). Their formation causes the reduction in strength and increase in deformability [28]. They cause loss of stone surfaces and architectural details.

The color of exterior surface of the andesite is more reddish brown than unweathered inner part. The SEM-EDS analysis of both parts indicated that the amount of $\mathrm{Fe}_{2} \mathrm{O}_{3}$ is higher than the unweathered samples. The $\mathrm{Fe}_{2} \mathrm{O}_{3}$ content varies between $7 \%$ and $15 \%$ in the sound parts while it reaches to $26 \%$ in weathered stone samples (Fig. 5). It can be explained by the dissolution of alkali/alkaline earth metals in the andesite $[29,30]$. In the first step, water percolates from surface to the interior parts of the rock by successive wetting and drying cycles. The iron containing alkaline earth metals are slightly dissolved in water inside of the stones. During evaporation, iron is migrated to the surface and precipitated

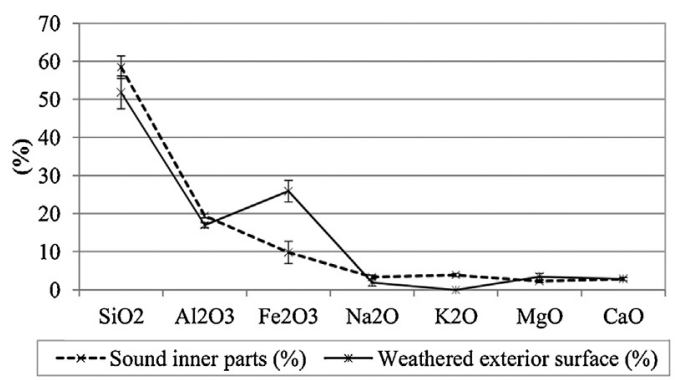

Fig. 5. Major and minor elements in unweathered andesite and weathered unburied andesite.

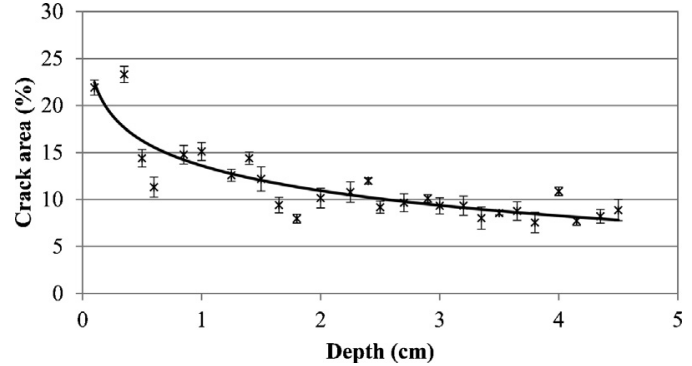

Fig. 6. Percent area of microcracks from weathered exterior surface to unweathered inner parts of unburied andesite.

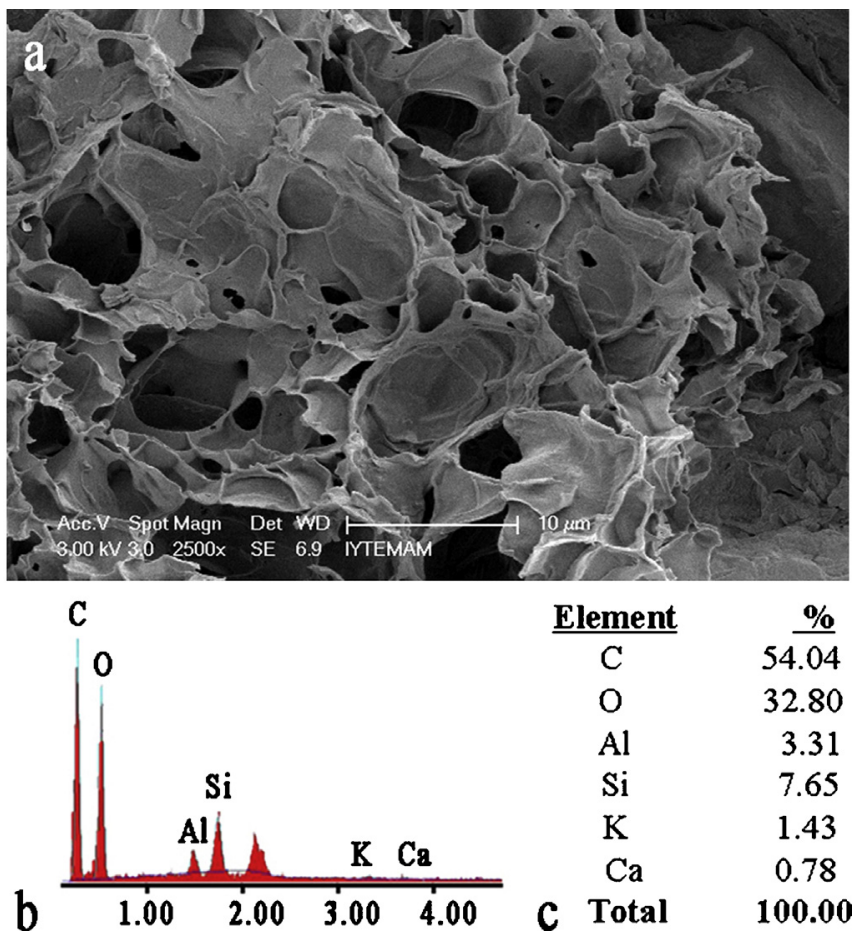

Fig. 7. (a) SE image, (b) EDX spectrum and (c) chemical composition of lichens taken from the exterior surface of unburied andesite.

as $\mathrm{Fe}_{2} \mathrm{O}_{3}$ which causes color change $[29,30]$. This process can be accelerated by excretion of organic acids produced by biological growth [10].

Andesite is primarily composed of silica minerals that are weathered by the effect of carbon dioxide and organic acids and turn into clay minerals over long periods of time [31,32]. XRD analyses show that the clay minerals formed in the stone are halloysite and illite (Fig. 4b). Their presence accelerates biological growth $[12,30]$.

SEM-EDS analysis of the deposits which cause color changes on the stone surfaces indicated that they contain high amounts of carbon and oxygen and low amounts of aluminum and silicon (Fig. 7). This shows the presence of biological growth due to the existence of clay minerals.

\subsection{Weathering of excavated andesite}

Physical weathering of the stones decreases due to nearly constant temperature and moisture during burial. Temperature and moisture content of the soil do not show as diverse varieties as in air $[27,33]$. Hence, physical weathering of stone proceeds in the soil slowly. However, after excavation, deposited soil and soluble salts may lead to a rapid weathering of stone. The main factors that affect 

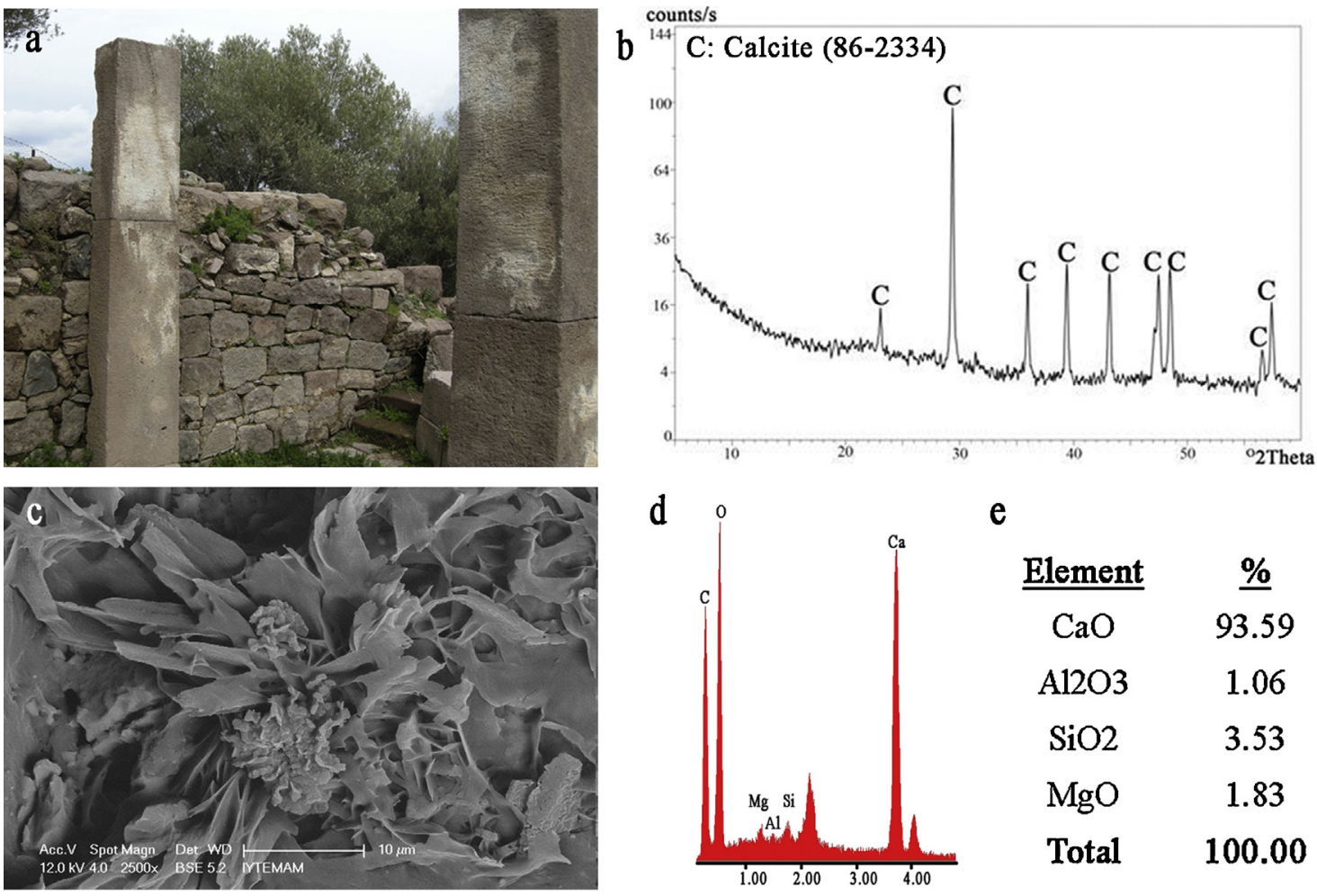

e

$\begin{array}{ccc}\underline{\text { Element }} & & \% \\ \mathrm{CaO} & & 93.59 \\ \mathrm{~A} 12 \mathrm{O} 3 & 1.06 \\ \mathrm{SiO} 2 & 3.53 \\ \mathrm{MgO} & 1.83 \\ \text { Total } & 100.00\end{array}$

Fig. 8. (a) White deposition observed on newly excavated andesite; (b) XRD pattern, (c) SE image, (d) EDX spectrum and (e) elemental composition of white deposition.

the weathering of buried stones are amount of soluble salts in soil, dissolved carbon dioxide, organic material content, soil reaction $(\mathrm{pH})$, vegetation cover and the particle size of the soil [13-16].

In this study, soluble salt contents of the five exterior stone and five soil samples were determined to estimate the salt weathering effects on the stone. The minor amounts of soluble salts less than $0.5 \%$ were found in the stone and soil samples. Main ions such as $\mathrm{NO}_{3}{ }^{-}, \mathrm{SO}_{4}{ }^{-2}$ and $\mathrm{Cl}^{-}$ions were not detected in any of the soil or stone samples. However, trace amounts of $\mathrm{PO}_{4}{ }^{-}$ions derived from soil were observed on the exterior surfaces. These results indicated that the effects of soluble salts are not effective for the deterioration of andesites.

Insoluble white depositions were observed on newly excavated andesites (Fig. 8a). Their mineralogical and chemical compositions were determined by XRD and SEM-EDS analysis. Analysis show that they are mostly composed of calcite $\left(\mathrm{CaCO}_{3}\right)$ (Fig. 8b-e). This formation can be explained by decay of calcium plagioclase feldspars with $\mathrm{H}_{2} \mathrm{O}$ and $\mathrm{CO}_{2}$ during burial since andesite and soil do not contain calcium carbonate (Calcite) (Fig. 9).

Calcium plagioclase feldspars (andesine, anorthite and labradorite) in the stone structure react with $\mathrm{H}_{2} \mathrm{O}$ and $\mathrm{CO}_{2}$ during burial. Calcium plagioclase feldspars decay and calcium bicarbonate and clay minerals are formed (Reaction (1)) [34]. After excavation, calcium bicarbonate move to the surface and water evaporated from the surface and calcium carbonate is precipitated (Reaction (2)) [34]. The formation of kaolinite inside of the stone and calcite on the surfaces can be explained with following reactions:

$$
\begin{aligned}
& \underset{\text { (Ca-Plagioclase) }}{\mathrm{CaAl}_{2} \mathrm{Si}_{2} \mathrm{O}_{8}+2 \mathrm{CO}_{2}}+3 \mathrm{H}_{2} \mathrm{O} \rightarrow \underset{\text { (Kaolinite) }}{\mathrm{Al}_{2} \mathrm{Si}_{2} \mathrm{O}_{5}(\mathrm{OH})_{4}}+2 \mathrm{HCO}_{3}^{-}+\mathrm{Ca}^{++} \\
& 2 \mathrm{HCO}_{3}{ }^{-}+\mathrm{Ca}^{2+} \leftrightarrow \mathrm{CaCO}_{3}+\mathrm{CO}_{2}+\mathrm{H}_{2} \mathrm{O}
\end{aligned}
$$

Petrographic and microstructural analyses of the three excavated stone samples from their exterior surface to the inner parts (approximately $2.4 \mathrm{~cm}$ ) indicated that the microcracks (Fig. 10a) were filled by clay minerals such as kaolinite, illite, halloysite, montmorillonite and saponite (Fig. 10b). The clay minerals may have penetrated to the stone structure from the soil or formed as a result of the chemical weathering of the feldspars in the stone structure [14].

Clay minerals swell and shrink with wetting and drying processes. In the process of swelling and shrinkage, cracks further propagate in the pores of the stone [12,35]. As far as promoting physical weathering, clay minerals also constitute appropriate environment for biological formations [12,31].

Rapid biological formations such as lichen, algae and fungi were observed after excavation and they promote the physical and

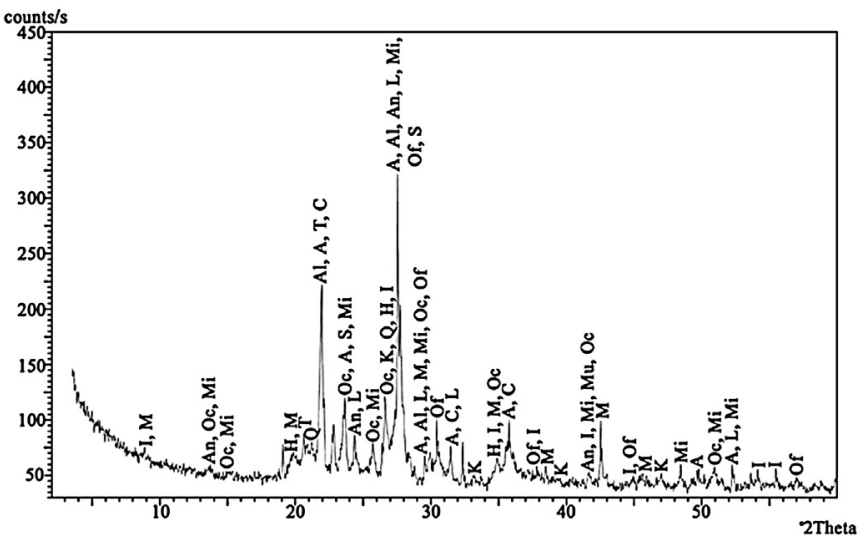

Fig. 9. XRD pattern of soil sample (A: Andesine (79-1148), Al: Albite high (831608), An: Anorthite (70-0287), C: Cristobalite (82-1403), I: Illite (15-0603), H: Halloysite (03-0184), K: Kyanite (72-1441), L: Labradorite (83-1368), M: Muscovite (76-0668), Mi: Microline (76-1238), Mu: Mullite (02-1160), Oc: Orthoclase (751190), Of: Orthoferrosilite (83-0668), Q: Quartz (83-2468), S: Sanidine (19-1227), T: Tridymite (42-1401)). 

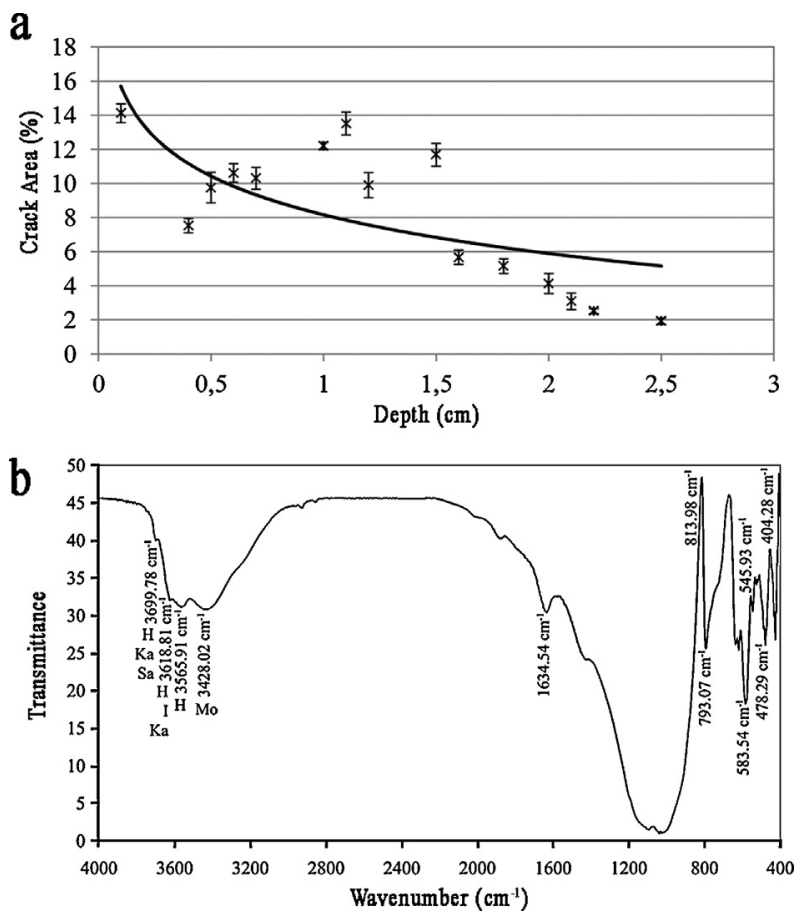

Fig. 10. (a) Percent area of microcracks from weathered exterior surface to unweathered inner parts of newly excavated andesite, (b) FT-IR spectrum of clay fraction observed in the cracks of newly excavated andesite (H: Halloysite, I: Illite, Ka: Kaolinite, Mo: Montmorillonite, Sa: Saponite).

chemical weathering of stones by penetrating the stone structure through the pores [31].

\section{Conclusions}

Unburied andesite monuments are mainly physically weathered by the formation of microcracks resulting from wetting-drying and freeze-thaw cycles. These cycles can also cause chemical weathering process of andesite minerals by the formation of clays on the exterior and interior parts. The existence of clay minerals accelerates the weathering of andesite by swelling and shrinkage and causes biological growth. The reddish brown color surfaces of the andesites are resulted by dissolution of iron containing alkali/alkaline earth metals by successive wetting and drying cycles.

As in unburied andesites, the clay minerals are formed in the newly excavated andesites due to weathering of silica minerals by the action of carbon dioxide and water during burial. The presence of clays on the stone surfaces and in the stone pores accelerates physical, chemical and biological weathering.

During burial conditions, calcium feldspars in the stone structure are weathered and soluble calcium bicarbonate is formed. After excavation, calcium bicarbonate solution move to the surface and water evaporates from the surface and calcium carbonate is precipitated. This process causes insoluble white efflorescence on the andesite surfaces.

The clay minerals formed on both unburied and excavated stones have to be cleaned from the surfaces and stabilized in the pores of the stones to control the physical and chemical weathering and biological colonization. Biological colonization has to be controlled by setting up drainage systems to prevent the penetration of water and through the use of biocides on the stone surfaces. Insoluble calcium carbonate precipitation on the andesite surfaces is a protective layer on the andesites and it is also a sign of the burial history of the archaeological monuments for centuries. Thus, this layer should not be cleaned from the stone surfaces.

This study shows that the archaeological excavations without conservation considerations cause higher weathering rate of stone materials. As a result, this study recommends reburying the excavated sites if the proper maintenance preventions cannot be maintained.

\section{Acknowledgements}

The authors thank to Prof. Dr. Ersin Doğer, Head of the Aigai Excavations, for his permission to let us study at the site and hospitality during the site survey and the researchers of the Centre for Materials Research at the İzmir Institute of Technology for XRD and SEM-EDS analyses during the experimental stage of this study.

\section{References}

[1] Recommendations of the Madrid Conference, http://www.getty.edu/ conservation/publications_resources/research_resources/charters/charter01. html, 1904 (accessed February 2012).

[2] The Athens Charter for the Restoration of Historic Monuments, http:// www.icomos.org/en/charters-and-texts?id=167:the-athens-charter-for-therestoration-of-historic-monuments, 1931 (accessed February 2012).

[3] The Recommendation on International Principles Applicable to Archaeological Excavations, http://portal.unesco.org/en/ev.php-URL_ID=13062\&URL_DO=DO_ TOPIC\&URL_SECTION=201.html, 1956 (accessed February 2012).

[4] The European Convention on the Protection of the Archaeological Heritage (revised), http://conventions.coe.int/Treaty/en/Treaties/html/143.htm, 1992 (accessed February 2012).

[5] D. Camuffo, Physical weathering of stones, The Science of the Total Environment 167 (1995) 1-14.

[6] J. Ashurst, F.G. Dimes (Eds.), Conservation of Building and Decorative Stone, Butterworth-Heinemann Series in Conservation and Museology, Butterworth-Heinemann, Oxford and Woburn, 1998.

[7] G. Grassegger, Decay mechanisms of natural building stones on monuments: a review of the latest theories, in: H. Geburtstag, W. Reinhardt, C.U. Grosse (Eds.), Werkstoffe und Werkstoffprüfung im Bauwesen: Festschrift zum 60, IWB, Stuttgart, 1999, pp. 54-81.

[8] B.J. Smith, M. Gómez-Heras, S. McCabe, Understanding the decay of stone-built cultural heritage, Progress in Physical Geography 32 (4) (2008) 439-461.

[9] A. Goudie, H. Viles, Weathering processes and forms, in: T.P. Burt, R.J. Chorley, D. Brunsden, N.J. Cox, A.S. Goudie (Eds.), The history of the study of landforms or the development of geomorphology, Geological Society of London, London, 2008, pp. 129-164.

[10] T. Warscheid, J. Braams, Biodeterioration of stone: a review, International Biodeterioration and Biodegradation 46 (4) (2000) 343-368.

[11] E. Doehne, C.A. Price, Stone Conservation - An Overview of Current Research, Getty Publications, Los Angeles, California, 2010.

[12] F. Press, R. Siever, Understanding Earth, W.H. Freeman and Company, New York, 2002.

[13] C.E. Thorn, R.G. Darmody, J.C. Dixon, P. Schlyter, Weathering rates of buried machine-polished rock disks, Kärkevagge, Swedish Lapland, Earth Surface Processes and Landforms 27 (2002) 831-845.

[14] B. Velde, A. Meunier, The Origin of Clay Minerals in Soils and Weathered Rocks, Springer-Verlag, Berlin Heidelberg, 2008.

[15] J. Curran, B. Smith, P. Warke, Weathering of igneous rocks during shallow buria in an upland peat environment: observations from the Bronze Age Copney Stone Circle Complex, Northern Ireland, Catena 49 (2001) 139-155.

[16] E.T. Power, Subsurface weathering of granitoid rocks in different climates, Ph.D. thesis, Queen's University, Belfast, Northern Ireland, 1989.

[17] R. Naumann, Eski Anadolu Mimarlığı (M. Ökmen, Trans.), Atatürk Kültür, Dil ve Tarih Yüksek Kurumu, Türk Tarih Kurumu Yayınları, Ankara, Turkey, 2007 (in Turkish).

[18] J.A. Howe, The Geology of Building Stones, Donhead Publishing Ltd, USA, 2001.

[19] W.K. Hamblin, E.H. Christiansen, Earth's Dynamic Systems, Prentice Hall, New Jersey, USA, 2003.

[20] E. Doğer, Aigai kazıları 2004-2006, Aigai excavation reports, İzmir, Turkey, 2006 (in Turkish)

[21] Herodotus, Herodot Tarihi (M. Ökmen, Trans.), I 149, Remzi Kitabevi, İstanbul Turkey, 1991 (in Turkish).

[22] F. Murtezaoğlu, Examination of deterioration problems of andesite used in Aigai Agora, Master thesis, İzmir Institute of Technology, İzmir, Turkey, 2009.

[23] Ç.D. Kaplan, Evaluation of stone weathering of Aigai Bouleuterion after its excavation, Master thesis, İzmir Institute of Technology, İzmir, Turkey, 2009.

[24] RILEM Commission 25 PEM, Tests defining the structure, Materials and Construction 13 (75) (1980) 177-181.

[25] C.A. Black, Methods of Soil Analysis, American Society of Agronomy, Wisconsin 1965. 
[26] J.M. Teutonico, A laboratory manual for architectural conservators, ICCROM, Rome, 1988.

[27] L.E. Spock, Guide to the Study of Rocks, Harper \& Row Publishing, New York, 1953.

[28] F. Arıkan, R. Ulusay, N. Aydın, Characterization of weathered acidic volcanic rocks and a weathering classification based on a rating system, Bulletin of Engineering Geology and the Environment 66 (4) (2007) 415-430.

[29] H.W. Müller, G. Riedmüller, B. Schwaighofer, Weathering products of andesitic rocks from Sulawesi, Indonesia, Clay Minerals 19 (1984) 21-28.

[30] T.C. Oguchi, Formation of weathering rinds on andesite, Earth Surface Processes and Landforms 26 (2001) 847-858.
[31] J. Chen, H.P. Blume, L. Beyer, Weathering of rocks induced by lichen colonization - a review, Catena 39 (1999) 121-146.

[32] P.C. Bennett, J.R. Rogers, W.J. Choi, Silicates, silicate weathering and microbial ecology, Geomicrobiology Journal 18 (2001) 3-19.

[33] J.M. Cronyn, The Elements of Archaeological Conservation, Routledge, Taylor \& Francis Group, London and New York, 2002.

[34] A.R. Berner, A.C. Lasaga, R.M. Garrels, The carbonate-silicate geochemical cycle and its effect on atmospheric carbon dioxide over the past 100 million years, American Journal of Science 283 (1983) 641-683.

[35] G.W. Scherer, Internal stress and cracking in stone and masonry, in: M.S. Konsta-Gdoutos (Ed.), Measuring, Monitoring and Modeling Concrete Properties, Springer, Dordrecht, The Netherlands, 2006, pp. 633-641. 